\title{
The Government as Shareholder and Principal-Principal Conflicts in the Brazilian Electric Power Industry
}

\author{
Murialdo Loch $^{1}$ \\ murialdosc@gmail.com | (D)0000-0003-4686-988X \\ Jaison Caetano Silva ${ }^{1}$ \\ jaisoncsilva@hotmail.com | (D)0000-0002-8737-152X \\ Giovana Bueno ${ }^{1}$ \\ giovanabueno2014@gmail.com | (D) 0000-0001-6270-8432 \\ Rosilene Marcon ${ }^{1}$ \\ rmarcon@univali.br | (D)0000-0002-0478-7715
}

\begin{abstract}
Considering that principal-principal conflicts in companies under mixed public-private ownership are substantially different from the typical agency conflict model, this paper's objective is to analyze principal-principal conflicts in mixed ownership companies in the Brazilian electric power industry. In order to expand understanding of the phenomenon which we are studying, we have integrated the assumptions that underlie agency theory and institutional theory, using a qualitative approach and collecting data during semi structured interviews with companies' board members. Data was analyzed and interpreted as per Bardin (2006), with the aid of ATLAS $^{\oplus}$ ti software. Our main findings suggest that while a government stake in a firm's ownership structure can provide a useful channel for the government to seek support and resources, in counterpoint, it can also create distortions and uncertainties, and exacerbate principal-principal conflicts. The development of stronger institutions and corporate governance could bring about useful options for providing checks and balances and, in the final analysis, mitigate principal-principal conflict. The article contributes to the literature by providing additional elements that are not available in public reports. Analysis of the conflict between principal and principal, together with theoretical integration, seek to broaden the understanding of this theme.
\end{abstract}

\section{KEYWORDS}

Government as Shareholder, Principal-Principal Conflicts, Corporate Governance, Institutions
${ }^{1}$ Universidade do Vale do Itajaí, Biguaçu, SC, Brasil

Received: $10 / 28 / 2018$ Revised: 01/22/2019. Accepted: 04/04/2019. Published Online: 11/11/2019.

DOI: http://dx.doi.org/10.15728/bbr.2020.17.1.2 


\section{INTRODUCTION}

Studies discussing the identity of shareholders (including the government) and their implications at the level of firms are still incipient. Furthermore, despite the importance of the subject, literature on agency conflicts has also been neglected, leaving many questions unanswered, including issues related to conflicts between the government as a majority shareholder, and other, minority, shareholders. The vast majority of studies in this area focus on agency conflicts between owners and managers, ignoring this phenomenon, which we will refer to as principal-principal conflicts (Branco \& Balassiano, 2013; Li \& Qian, 2013; Young, Peng, Ahlstrom, Bruton \& Jiang, 2008).

In the case of emerging countries, which are marked by weak institutions and turbulent environments, it is highly relevant to understand the dynamics and effects of principal-principal conflicts in companies that are under mixed public-private ownership. Not all of the mechanisms of state influence on firms are known, such as, for example, to what extent state participation is beneficial or harmful to firms, and the potential effects of this participation on principal-principal conflicts, which raise intriguing questions that remain to be answered.

Boubakri, Ghoul, Guedhami, and Megginson (2018) describe two conflicting views, one in favor and other against government control. While government ownership and control are expensive-because politicians use firms to pursue objectives other than the maximization of profit—conversely, government participation affords easier access to funding and support during periods of financial difficulties.

In Brazil, state participation in firms has been significant in recent decades, which saw a scenario of considerable change in the organizational environment, such as growth in the number of new firms listed on the stock exchange, mergers and acquisitions involving large companies, the global economic crisis, and many scandals involving both firms and the political sphere (Silva, Xavier, Gambirage, \& Camilo, 2018).

Considering the many factors making principal-principal conflicts in mixed ownership firms substantially different from the typical model of agency conflict investigated in the majority of studies (Young et al., 2008), the objective of this paper is to analyze principal-principal conflicts in companies under mixed public-private ownership in the Brazilian Electric Power Industry (BEPI). In order to expand understanding of this phenomenon, we have integrated assumptions underlying both agency theory and institutional theory, and then adopted a qualitative approach.

Drawing on work by Jensen and Meckling (1976), North (1990), La Porta, Shleifer, and Lopez-de-Silanes (1999), Lazzarini and Mussachio (2010), Young, Peng, Ahlstrom, Bruton and Jiang (2008), and Li and Qian (2013), we conducted a qualitative research project, collecting data by means of interviews conducted with a semi structured script.

The interviewees were chosen intentionally. We selected three board members and two directors with high levels of experience in the BEPI, three of whom were representatives of private investment funds, one who was an indirect representative of the government, via a pension fund, and one being a direct representative of the government, making a total of five interviewees.

We used the conceptual foundation and analytical procedures developed by Bardin (2006) to analyze the interview data, with the aid of ATLAS ${ }^{\circ}$ ti software. This software was used to classify interviewees' responses according to predetermined categories. Once the utterances had been sorted, the software was used to build networks, providing a clearer picture of the connections between categories. We then divided the analysis into the three stages recommended by Bardin (2006): a) pre-analysis, b) exploration of the material and c) treatment of the results, inference, and interpretation. During pre-analysis, the interviews were organized with the objective of making them operationalizable, systematizing them by means of a "free-floating reading". The second 
phase consisted of exploration of the material, and a definition of categories. The third phase comprised inference and interpretation, with reflective analysis in light of the theories adopted.

Our main findings suggest that direct participation by the government as the majority shareholder in firms in regulated markets, such as the BEPI, creates a situation of potential conflict and uncertainty for investors. This results from divergent firm objectives, and are minimized when mechanisms for corporate governance remain present in the firm and regulatory agencies are not captured by the state.

We argue that government holdings in firm ownership structures can provide a useful channel to the government for firms seeking both support for projects that demand investments that mature over the long term, as well as guarantees in times of crisis. However, in counterpoint, they can also create a series of distortions as caused by the government's desire to pursue projects based on political criteria. Development of institutions and corporate governance could furnish useful options in the search for checks and balances to control opportunistic behavior and regulatory capture and, in summation, could mitigate the principal-principal conflict

Having integrated the assumptions that underlie agency theory and institutional theory, in order to explain principal-principal conflicts, we have shown that this integration makes positive contributions to the debate and helps explain the phenomenon, particularly in the context of emerging economies. By using a qualitative approach to investigate elements not available in the secondary data published by companies, we were able to read between the lines of company reports and understand phenomena not covered in disclosures. It should be emphasized that we were able to obtain primary data from important actors by use of this process, considering that companies in this industry would be very unlikely to authorize this type of research, and do not usually go beyond provision of the information that they are obliged to disclose, either by law or by regulatory authorities. This underscores the contribution this study makes to the debate on the subject.

\section{LITERATURE REVIEW}

\subsection{Agency Theory and Institutional Theory}

While discussions of government participation in the economy are not a recent development, the subject remains current. Explanations of the extent to which the government should participate in the market are of increasing interest in both academic circles and everyday life. The debate on the value of direct state presence in companies often becomes polarized, with many taking the side that the separation of state and firm would be preferred.

It is worth observing that there is no consensus or conclusive elements in the literature on this subject. The relative success of Chinese state-owned enterprises has resulted in this model being considered a relevant alternative option which has reduced the inclination to privatize. This dynamic has led academics, albeit in an incipient manner, to make efforts to improve the understanding of the subject (Stan \& Bruton, 2013).

Specifically, the history of the Brazilian electric power industry (BEPI), which is the industry of focus for this study, has seen dramatic oscillations between state and private ownership, starting from its inception in the 1880 s up to the 2010s. The BEPI has gone from a private monopoly in its first decades to a state-owned model from the 1960s to the 1980s, before adoption of a hybrid model in the 1990s. Many firms in the industry have been in this public/private grey area since the start of the current decade. 
It should be noted that, even with the process of reducing state participation, and the introduction of the hybrid model, there is still clear evidence that state intervention in these firms is on the rise, whether the state acts as regulator, or as a direct or indirect shareholder (Lazzarini, 2011). In the literature, agency theory points out that state ownership creates a series of distortions caused by the government's inclination to force firms to nominate politicians to management positions or to run projects on the basis of political criteria, rather than seeking efficiency and profitability (Cuervo \& Villalonga, 2000; Shleifer \& Vishny, 1994).

Interference in company administration by politicians on the board, who have been selected to meet political criteria and not for their management skills, can be harmful to firm performance. (Fan, Wong, \& Zhang, 2007). For example, wage costs can rise, the number of employees may be increased, investment could be ramped up to coincide with electoral cycles, and accounting may be distorted, leading to penalization by market forces (Bertrand et al., 2007; Gul, 2006; Shleifer \& Vishny, 1994).

These characteristics, combined with poorly developed institutions and a lack of effective governance mechanisms, make investors vulnerable. This scenario makes it difficult to make reliable projections of return on investment, and exacerbate conflicts between controlling and minority shareholders (Dharwadkar, George, \& Brandes, 2000; Khanna \& Palepu, 1997; Morck, Wolfenzon, \& Yeung, 2005).

Agency theory is the leading theoretical approach to the relationships and conflicts that result from the separation of ownership from control. Such conflicts can involve many different actors related to the firm and their respective interests, as illustrated in Chart 1.

The diversity of interests and expectations of the different actors, as well as the difficulty of determining whether the different parties behave appropriately, and the likelihood that they will have different attitudes to risk, are all elements that contribute to the complexity of balancing interests in relation to the firm (Eisenhardt, 1989).

Chart 1

Relationships between parties involved

\begin{tabular}{|c|c|c|}
\hline Actor 1 & Actor 2 & Actor 1's expectations of Actor 2's actions \\
\hline Shareholders & Management & Maximization of their wealth \\
\hline Bondholders & Management & Guarantee their returns \\
\hline Creditors & Management & Fulfillment of loan contracts \\
\hline Customers & Management & $\begin{array}{l}\text { Delivery of value-added products that meet their preferences } \\
\text { (quality, time, service, and price) }\end{array}$ \\
\hline Government & Management & $\begin{array}{l}\text { Fulfillment of the firm's tax, employment, and social security } \\
\text { obligations }\end{array}$ \\
\hline Community & Management & $\begin{array}{l}\text { Defense of community interests, culture, values, and the } \\
\text { environment. }\end{array}$ \\
\hline Management & Employees & Work to the best of their ability, to meet management expectations \\
\hline Management & Suppliers & $\begin{array}{l}\text { Supply of material requirements, at the time needed and in the } \\
\text { quantities ordered }\end{array}$ \\
\hline $\begin{array}{l}\text { Principal (minority } \\
\text { shareholders) }\end{array}$ & $\begin{array}{l}\text { Principal (majority } \\
\text { shareholders) }\end{array}$ & $\begin{array}{l}\text { Guarantee their interests so that there is no expropriation of their } \\
\text { wealth }\end{array}$ \\
\hline
\end{tabular}

Source: Adapted from "Theory of Firm: Managerial Behaviour, Agency Costs and Ownership Structure" by Jensen, M. C. and Meckling, W. H. 1976, Journal of Financial Economics, p. 305-60; "Corporate Ownership around the world." by La Porta et al., 1999, The Journal of Finance, 54(2): 471-517; and "Corporate Governance in Emerging Economies: A review of the Principal-Principal perspective" by Young et al., 2008, Journal of Management Studies, v. 45 , p. $196-220$. 
BBR

17

28

Despite the subject's relevance, the literature on agency conflicts has neglected, or is inconclusive with relation to several aspects related to shareholder conflicts. Particularly, there is a lack of literature regarding cases where the government is the majority shareholder, literature on the implications of this for minority shareholders, and related analyses at the level of the firm, since the vast majority of research in this area focuses on agency conflicts between owners and managers (Jensen \& Meckling, 1976; La Porta et al., 1999; Lazzarini \& Mussachio, 2010; Young et al., 2008). These gaps highlight the importance of this study.

Companies in which the government is the majority owner are normally subject to greater interference from politicians attempting to use them as mechanisms to transfer funds to further their political plans (Shleifer \& Vishny, 1998). Additionally, governments may seek to achieve dual objectives, such as, for example, increasing employment and lowering prices for consumers, in addition to reaching profitability targets (Mengistae $\& \mathrm{Xu}, 2004$ ). Boubakri, Ghoul, Guedhami, and Megginson (2018) found evidence that the market places higher values on state-owned companies than on those that are not state owned, whereas, in a study by Beuselinck, Cao, Deloof, and Xia (2017), the shares of companies with government holdings lost value. They also observed that the government only has a positive effect in countries with good investor protections and low levels of corruption.

The influence on firms by actors who hold shares, the government in particular, is more intense in emerging economies than in developed economies, and there are also different institutional arrangements (Hoskisson et al., 2000). Regarding this difference in institutional structures, Khanna and Palepu (1997) have termed the absence of regulatory, coercive, and punitive mechanisms as "institutional voids". These institutional voids lead to opportunistic behavior and elevated risk for firms (Hoskisson et al., 2000), in addition to problems such as incorrect regulation, ineffective judicial systems, shortages in capital markets, and prioritization of political objectives in detriment to economic objectives (Khanna \& Palepu, 1997).

In these situations, corporate governance offers mechanisms to balance costs and minimize the value lost because of conflicts of interests between decision makers and those investing in the firm (Cuervo-Cazurra \& Dau, 2009; Peng, Wang, \& Jiang, 2008; Shleifer \& Vishny, 1997; Silveira, Barros, \& Fama, 2008;). However, internal mechanisms such as, for example, the board of directors, need strong support from external mechanisms, such as the legal system, in order to be able to adequately fulfill their roles. In this respect, emerging economies are characterized by providing weak support for company directors (Young et al., 2008).

The principal factors of differentiation between corporate governance models are related to the concentration of shareholder ownership in each country and the strength of legal protections for investors (Shleifer \& Vishny, 1997; La Porta et al., 1999). Developed economies have institutional protections for minority shareholders and market institutions are well founded. However, in emerging countries there is a large proportion of ownership concentration (Dharwadkar et al., 2000) and such protections do not exist (Young et al., 2008).

The combination of weak institutions and the absence of effective governance mechanisms results in more frequent agency conflicts between shareholders with controlling stakes and minority shareholders (Khanna \& Palepu, 1997; Morck et al., 2005). Together, all of these factors make principal-principal conflicts substantially different from the typical model of agency conflict, as presented in the majority of studies (Young et al., 2008).

Considering that history can provide an important perspective from which to understand the effect that the institutional environment can have on the economy and on businesses (North, 1990), Figure 1 summarizes the most important changes that have taken place in the electric power industry in Brazil, from its foundation to the 2010s. 


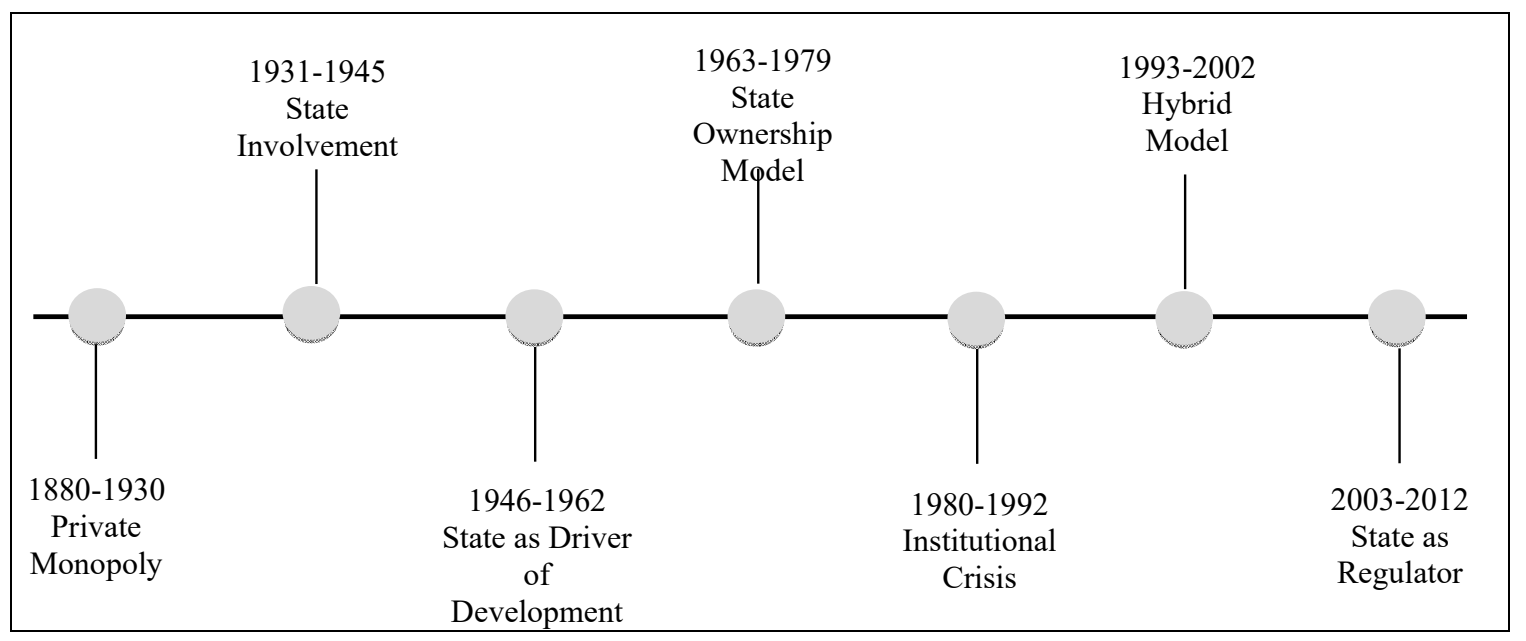

Figure 1. Timeline.

Source: Adapted from Gomes and Vieira (2009) and Musacchio and Lazzarini (2015).

Of particular note is the program to reduce state participation that took place during the 1990s. However, the pension funds of both state-owned companies and the national development bank (BNDES) played a leading role in these privatizations. As a result, the government retained control of a considerable proportion of economic activity through a mixture of state-owned companies, the BNDES, or companies that were controlled indirectly via pension funds (Lazzarini, 2011).

Brey, Camilo, Marcon and Bandeira-de-Mello (2014) conducted exploratory research investigating the effects of Brazilian federal, state, and municipal government holdings in the ownership structures of companies. They found that government involvement comprises a significant proportion of the economy, with holdings in $13.71 \%$ of the publicly traded companies listed on the B3 stock exchange. In the period from 1999 to 2010, government held an average of $49 \%$ of voting shares and $39 \%$ of the total of all shares in all companies, which indicates that governments control companies that they are directly involved in. The results also showed that governments diversify their corporate relations across industries, since they are not concentrated in a selection of key industries, but instead maintain differing levels of involvement in all sectors of the economy.

The Brazilian government, therefore, has many ways of influencing the decision-making processes of businesses. An important point that must be stated, with respect to the state's double role, as owner and regulator, is the need for safeguards against the possibility that the regulator may be hostage to the public/mixed companies which themselves may be serving political interests (Arvate, 2013; Bauer, 2005; Lazzarini \& Musacchio, 2010; Musacchio \& Lazzarini, 2015), which, in summation, exacerbates the principal-principal conflict.

Figure 2 summarizes the government's influence on the BEPI and the mechanisms it has used for exerting this influence at the end of the 2010s. The National Electrical Energy Agency (ANEEL) and the Ministry of Mines and Energy (MME) are the primary entities with influence, while the National Energy Policy Council (CNPE) and the Electricity Industry Oversight Committee (CMSE) are ancillary bodies of the MME. Note that the MME also has influence over ANEEL, which contributes to further increasing its influence over the concession holders.

Concentration of these roles (concession grantor, regulator, and shareholder) also points to the possibility of government interference in the many different interfaces of the BEPI. For example, the widespread and commonplace practice of the politically motivated appointments of 


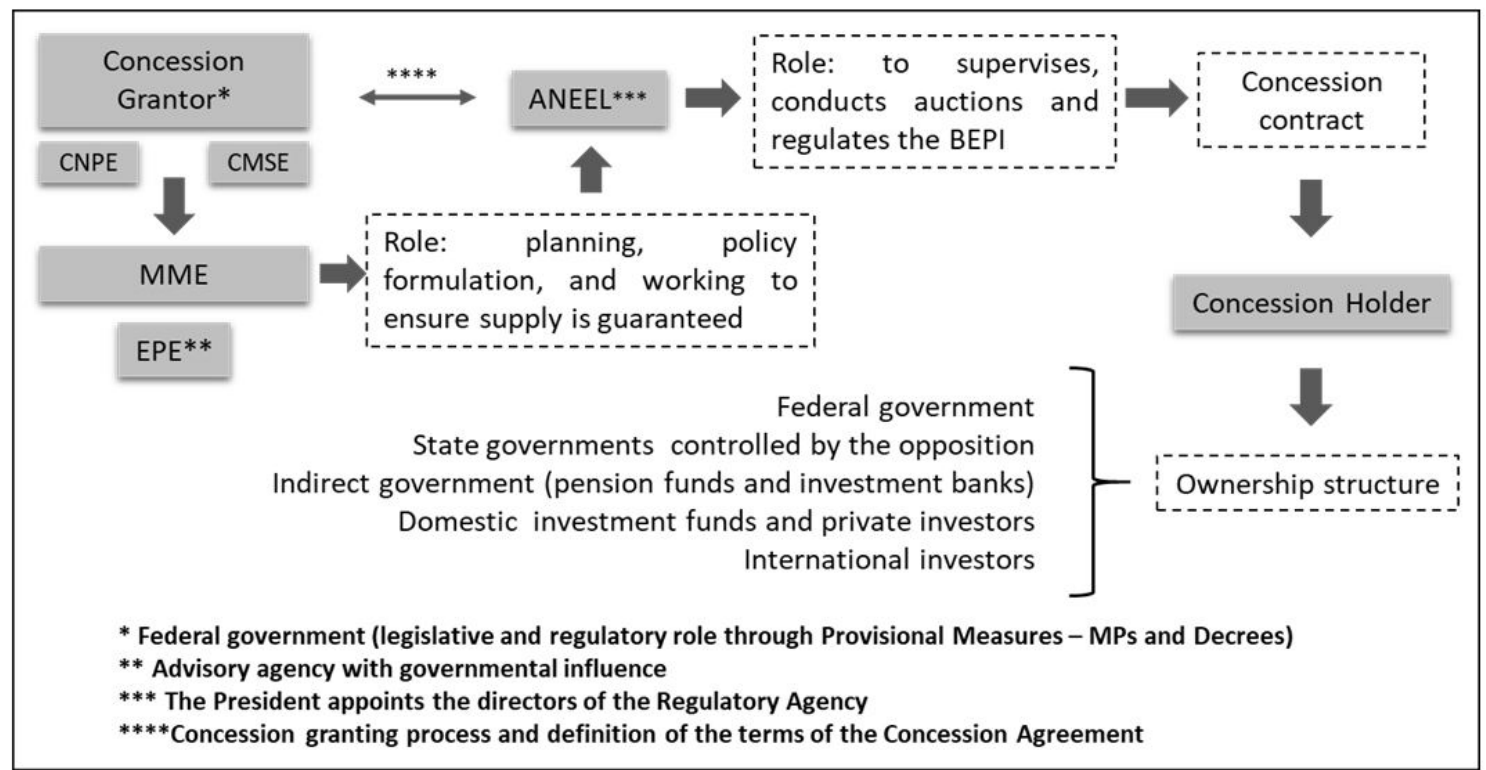

Figure 2. The government as concession grantor, shareholder, and regulator in the Brazilian electric power industry

Note: The acronym ERC** stands for Energy Research Company.

Source: prepared by the authors (2019).

candidates to management positions in ANEEL can be traced through news media, as shown by Wiziack (2018), Costa (2018), and Rocha (2013). The involvement of politicians in nominations to ANEEL, demonstrated by Wiziack (2018) and Costa (2018), reinforces findings by Arvate et al. (2013), who showed that the quality of the regulatory environment can have a direct influence on firm performance. According to Nunes, Ribeiro and Peixoto (2015), the workings of these regulatory agencies have been criticized, whether for exceeding their mandates and the scope of their role of regulator, for proposing and implementing public policies, or because of the politicization of nominations for top management positions.

In regards to state-owned enterprises, Rocha (2013) points out that direct government influence on their decision-making, through the wishes of shareholders, has demonstrable effects on their performance. Governments in Brazil have very specific means for influencing firms: through direct participation in their ownership structures (public companies, state owned enterprises, federal agencies, national or regional development banks, social development funds, and obligatory social contribution funds), through indirect ownership (via the pension funds of public and state-owned companies), and through the governments of individual states (Lazzarini, 2011; Brey et al., 2012, p. 107).

In this scenario, the board of directors has greater significance in Brazilian companies, due to the significant presence of institutional investors, as well as foreign investors, along with their determination to maintain their representation on the board, and in monitoring the firm. This monitoring role is especially useful in situations in which the government, as controlling shareholder, attempts to use the firm's resources for political purposes, which implicates the other minority shareholders in dividing the costs (Bebchuk \& Weibsbach, 2010; Johnson, Schnatterly, \& HILL, 2013; Okimura, Silveira, \& Rocha, 2007).

Another point worth noting relates to conflicts of interests affecting decisions taken by concession holders, since the government as shareholder is at one pole, where it seeks to maximize profit and firm value, while the government as concession granting authority is at the other 
pole, seeking social wellbeing. This polarity accentuates agency problems between shareholders (these problems are treated as principal-principal conflicts in this paper). As a result, since the government's objectives are more focused on social value, the state tends to be more generous with the return on investment, particularly during turbulent periods, which may not be the objective of the other owners (Kaldor, 1980).

In essence, it can be observed that state ownership can provide the firm with a direct channel to the government when seeking support for projects requiring investments that mature over the long term, particularly in areas that are strategic for the country. However, it can also create a series of distortions, caused by the government's inclination to transfer revenues to meet its political needs and pursue projects founded on political criteria, rather than targeting efficiency and profitability (Bertrand, Kramarz, Schoar \& Thesmar, 2007; Cuervo-Cazurra \& Villalonga, 2000; Gul, 2006; Mengistae \& Xu, 2004; Shleifer \& Vishny, 1997).

Hand-in-hand with this situation, the low level of institutional development in emerging countries is an obstacle to creation of checks and balances, as well as making reliable predictions of return on investment difficult, leaving investors vulnerable, accentuating opportunistic behavior, and being a contributing factor to regulatory capture in the interests of public and public-private firms, which, in the final analysis, exacerbates principal-principal conflicts (Arvate, Kallás, Gama, Lopes Júnior, \& Bandeira-de-Mello, 2013; Bauer, 2005; Fontes Filho \& Picolin, 2008; Hoskisson et al., 2000; Khanna \& Palepu, 1997; Musacchio \& Lazzarini, 2015).

\section{METHODOLOGICAL PROCEDURES}

In terms of approach, this is a qualitative study with data collection conducted in interviews with board members and directors from the industry using a semi structured script. Interviewees were chosen intentionally.

The interview data was analyzed using a conceptual foundation and procedural stages described by Bardin (2006), with the aid of ATLAS ${ }^{\oplus}$ ti software. This choice was made because Bardin is the author with the greatest degree of recognition and the most often cited in research that adopts content analysis as a data analysis technique (Mozzato \& Grzybovski, 2011). There were, therefore, three analytical phases: a) pre-analysis, b) exploration of the material, and c) treatment of the results, inferences, and interpretations.

During the pre-analysis, the interviews were organized with the objective of making them operationalizable, systematizing them by means of a "free-floating reading", to form an overview of the interviews as a whole, choosing relevant passages, and demarcating those that would be analyzed. The second phase consisted of exploration of the material, the definition of categories, and the identification of both units of meaning and of units of context within the interviews. The third phase comprised treatment of the results, inference, and interpretation, and it is in this phase that information was condensed and highlighted, culminating in inferential interpretations, in the light of reflective analysis (Bardin, 2006).

The interviews were conducted from August to November of 2016 and were recorded and transcribed in order to ensure traceability and reliability. Each interview had a mean duration of one hour and adhered to the ethical principles of free and informed consent; interviewees were informed of the purposes of the research, their anonymity was preserved, and they were told that they could terminate the interview and withdraw consent at any point with no need to provide explanations of any type. As part of the process for maintaining confidentiality, the interviewees were assigned codes, as shown in Chart 2. 
BBR

17

32

Chart 2

Interviewee codes

\begin{tabular}{ll}
\hline Code & Profile Of Interviewee \\
\hline INT 1 & $\begin{array}{l}\text { Currently a director of a BEPI firm, representing indirect government participation as a minority } \\
\text { owner. }\end{array}$ \\
INT 2 & $\begin{array}{l}\text { Currently a director of a BEPI firm, representing direct government participation as a majority } \\
\text { owner. }\end{array}$ \\
INT 3 & $\begin{array}{l}\text { Currently a board member, and previously a director of a BEPI firm, representing a private } \\
\text { investment fund with a minority holding. }\end{array}$ \\
INT 4 & $\begin{array}{l}\text { Currently a board member representing indirect government participation as a minority owner. } \\
\text { Currently a board member of a BEPI firm representing a private investment fund; was previously a } \\
\text { INT } 5\end{array}$ \\
\hline
\end{tabular}

Source: prepared by the authors (2019).

The interviewees were three board members and two directors with a great deal of experience in the BEPI. Three were representatives of a private investment fund, one was an indirect representative of the government via a pension fund, and the last was a direct representative of the government, making a total of five interviewees. The average interview duration was one hour.

The interviewees were chosen intentionally and with regard to accessibility, since the sensitivity of the subject (political interference and conflicts of interests) meant that few potential informants would be willing to participate, even under condition of anonymity. While, in terms of absolute numbers, the size of the sample is relatively small, these interviewees are highly representative in terms of their understanding of, and experience in, the industry, enabling us to investigate our phenomenon with propriety and confidence. Interviews were recorded so the content could be verified and double-checked at any time, which guaranteed traceability and verifiability.

The questions asked were inspired by the relevant literature and recorded in an interview script. The participants were interviewed formally, adhering to the script of specific questions (Appendix B), and each subject broached has its foundations in theory, as shown in Chart 3.

Chart 3

Areas of analysis

Areas of analysis Definitions/authors

Corporate governance is the set of mechanisms for ensuring investors their return on

Corporate investment and for conducting the firm's economic activity (Cuervo-Cazurra; Dau, 2009;

governance La Porta et al., 1998; Peng et al., 2008; Shleifer; Vishny, 1997).

The board should play an internal role, conducting intense monitoring and protecting the interests of shareholders (Johnson et al., 2013).

Principal-principal Principal-principal conflicts occur when majority shareholders abuse their controlling stock holdings to obtain benefits (Dharwadkar et al., 2000).

The identity of owners has implications for objectives and the ways in which owners exercise their power is an important element of corporate governance (Thomsen; Pedersen,

Shareholder identity 2000).

With relation to shareholder identity, in Brazil, the government can become a shareholder indirectly via the pension funds of public and state-owned companies, such as the Caixa Economica Federal Pension Fund, the Banco do Brasil Workers' Pension Fund and the Petrobras Social Security Foundation (Lazzarini, 2007).

Regulation is the institutional arm created by governments for resolving problems that framework occur when there are market failures, with different characteristics that vary between countries (Arvate et al., 2013).

Source: prepared by the authors (2019). 
Primary data was transcribed and subjected to textual analysis. Responses were weighted to ensure that the analytical process for extraction of relevant content was conducted scientifically. This content was selected on the basis of its connections with the subjects of interest, so that the information could be compiled and analyzed in terms of its relevance to the study (Miles \& Huberman, 1994).

Each interview transcript was read carefully and in detail, constructing an initial draft of the analytical categories by tracing recurrent patterns in interviewees' responses. The categories were defined with the intention of organizing, retrieving, and condensing the data (Miles \& Huberman, 1994). Finally, evidence tables were drawn up to interrelate and group the evidence related to each category.

Responses were examined and considered with the objective of extracting content relevant to the categories defined. Content was selected and categorized according to its relevance to each of the subjects chosen for analysis. One category emerged that had not been included when the interview script was developed, but which was compatible with the way the study unfolded. At the end of the process, six categories had been defined. Five of the categories conformed to the predefined subjects and one that emerged during analysis.

The interviewer's personal values and expectations were carefully monitored to avoid influence on the conclusions. At the end of the interview, interviewees were consulted to avoid erroneous interpretations of the information, thereby attending to internal validity (Creswell, 2010). The information extracted from the interviews was organized into four main categories that encompassed the subjects investigated in the study (shown in Chart 4).

Chart 4

Analytical areas and categories

\begin{tabular}{lll}
\hline Areas Of Analysis & \multicolumn{2}{c}{ Categories } \\
\hline Corporate governance & Category 1 & $\begin{array}{l}\text { Corporate governance in Brazil } \\
\text { Board of directors }\end{array}$ \\
Principal-principal & Category 2 & $\begin{array}{l}\text { Principal-principal conflict } \\
\text { Role of majority shareholder }\end{array}$ \\
Shareholder identity & Category 3 & $\begin{array}{l}\text { Government as shareholder } \\
\text { Regulatory agencies }\end{array}$ \\
Regulatory framework & Category 4 & $\begin{array}{l}\text { Influence of the government on the industry } \\
*\end{array}$ \\
\end{tabular}

Note: $*$ category that emerged from the interviews.

Source: prepared by the authors (2019).

The last category listed in Chart 4, MP 579/12, emerged during the interviews and merits further explanation. The label, MP 579/12, refers to a major change to electric power industry regulation that occurred in 2012 and was initially enacted through an executive order known as a Provisional Measure. Although it was later passed into law in the form of standard federal legislation (BRAZIL, 2012a; BRAZIL, 2012b), the regulatory framework that it introduced has become known as MP579/2012 throughout the industry. This framework covered concessions for electricity generation, transmission, and distribution, setting out the minimum standards of service provision and defining procedures for which firms in financial difficulty could use to file for protection from creditors.

As detailed by Loch et al. (2018), the Brazilian federal government justified the regulatory changes based on the possible reduction of energy costs for the final consumer. In this way, the 
government changed taxes and tariffs and set limits on dealers' profit margins in an attempt to preserve the sector's economic structure and protect jobs. With this measure, the government projected a savings for consumers of over $20 \%$. However, in practice the average reduction was less than $17 \%$. The measures had serious impacts on the concession holders, but the effects varied depending on the ratio of fixed to total assets and the time since acquisition of fixed assets. For example, distribution concession holders were threatened with insolvency because of the high wholesale energy price and the inability to pass increases on to their customers, combined with an absence of tax incentives.

\section{PRESENTATION AND ANALYSIS OF THE DATA}

In the opinion of the interviewees, corporate governance in the Brazilian setting has improved since it was first implemented in companies, but there is still a long way to go. The majority of existing governance practices are limited to compliance with legislation, i.e. they do not focus on management excellence, on meeting international standards, or on the market.

They referred to the Brazilian Corporate Governance Institute (IBGC) as an institution that plays an educational role. In contrast, the capital markets regulatory agency, the CVM, is mentioned, with relation to this subject, as being a potential ally in implementation of best corporate governance practices, i.e., practices that are more robust and proactive, capable of protecting investors from inappropriate interventions in the way business and operations are conducted. Chart 5 contains some quotes from the interviews that illustrate these claims.

Chart 5

Category: Corporate governance in Brazil

Category Data

INT 1: In some cases, Governance is very high quality, but there is still much to be achieved. [...] the CVM should be involved more [...] companies should pay greater attention to what the IBGC is saying.

INT 2: There has been progress, but I think that this is a fertile field for achieving more. INT 3: We're going at a crawl, because we need to take some steps in other areas [...] the Corporate regulator's role is fundamental.

governance INT 4: The level of governance. Here, yes! This is one movement in which listed companies in Brazil have progressed a lot [...] the IBGC, which, as a non-profit institution, plays more of an educational role in convincing listed companies.

INT 5: I think that corporate governance in Brazil is still in an initial phase [...] overall, my impression is that in the majority of companies it exists to perform certain rituals that are defined by the law [...] the IBGC plays an idealistic and generic role in relation to the general conditions of governance [...] it is the industry regulators that should be the great champions in defense of adequate governance standards for the firms in their industry.

Source: prepared by the authors (2019).

The results also confirmed a study by Shleifer and Vishny (1997) who showed that corporate governance is an important mechanism through which investors can ensure that they will obtain return on their investment, primarily when supported by regulatory, legal, and market mechanisms.

One governance mechanism that merits focus is the board of directors which, in the interviewees' opinions, is of significant importance to conducting corporate management, especially its degree of professionalism and independence. The counterpoint to this is that conflicts may be more common. However, conflicts tend to be positive, influencing more objective decisions, and 
contributing to firms' sustainability, making difficult arbitrary decisions, or decisions that benefit the interests of specific groups.

The interview results in Chart 6 show that the numerical composition of the board seems

to be less relevant than its professionalism and independence, but the numbers are seen as the bellwether of the efficiency of the governance process, in that the number of board members is not necessarily related to their quality, nor to the management they provide.

Chart 6

Category: Board of directors

\begin{tabular}{ll}
\hline CATEGORY & DATA \\
& INT 1: A Board that is professional and is interested in the results, the profitability of the firm, \\
& makes all the difference [...] a proportion of independent board members. [...] need extremely \\
& professional people. \\
& INT 2: It is very important to have an independent board member, because he has no \\
& obligations to A or to B.
\end{tabular}

Source: prepared by the authors (2019).

These statements confirm that the board can be considered as an important instrument that owners can use for monitoring the firm, particularly in situations in which a controlling shareholder uses the firm's resources for their own benefits, while minority shareholders are left to share out the costs (Bebchuk \& Weisbach, 2010; Johnson et al., 2013; Okimura et al., 2007).

Another finding worthy of note is that the interviewees stated that the number of board members is not as relevant as their qualifications or independence. This is especially important in relation to quantitative studies that use the number of board members as a variable, since, in addition to the size of the board, it is relevant to include variables in the model that control for their level of independence, common in some studies, and also variables related to board members' qualifications, which represents both a challenge and an opportunity for researchers investigating the subject.

It can be observed from the quotations in Chart 7 that the respondents are very clear about the role and power of the majority shareholder, stating that, in practice and in day-to-day operations, these shareholders have effectively direct influence over the direction of corporate policies and decision-making. It can be inferred that if some type of change becomes necessary to a firm, the majority shareholder's agreement is a determinant condition for the change to be effected.

Also of note is the interviewees' emphasis on the influence that the majority shareholder has on the organization's performance, which does, in fact, take place. It is also evident that the interviewees consider the minority shareholders' influence as proportional to their shareholdings. They state that there would be no conflict with the private minority investors if the majority shareholder strove for firm performance. These interviewees, therefore, confirm what Li and Qian (2013) have stated: it is concentration of ownership, in combination with weak institutions (the regulatory framework), that cause conflicts between shareholders when the objectives of the controlling and the minority shareholders do not converge on the maximization of results. 
Chart 7

Categories: Role of Majority Shareholder and Principal-principal conflict

Source: prepared by the authors (2019).

Principal-principal conflicts would therefore be mitigated if the objectives of minority and majority shareholders were convergent, i.e., if the former sought firm performance and financial health to the same extent as the latter. Li and Qian (2013) are in agreement, stating that concentration of ownership, compounded by weak institutions (the regulatory framework), is the cause of conflicts between shareholders when the objectives of the controlling and the minority shareholders do not converge on the same result.

However, no matter how much the minority investors use the mechanisms of governance available to them, it still appears that they are ineffective, depriving minority shareholders of their return on investment, and bringing the principal-principal conflict into existence. In the opinion of the interviewees, the minority shareholders' objective is profitability, but they receive little information and are generally ignored in decision-making. Additionally, conflicts emerge between political interests (government) and private interests, in which the first is not always as interested in the financial health of the firm as the second.

These results underscore the position of Leal and Saito (2003) who argue that the central issue lies in the ways that minority shareholders are protected from the actions of controlling shareholders. They also support the point made by Li and Qian (2013) that the existence of weak institutions has been identified as the "root cause" of conflicts between shareholders, defined as incompatibilities between the objectives of groups of shareholders in a firm, in particular between controlling shareholders and minority investors. This, in summation, is also aligned with Young et al. (2008), who concluded that all of these factors make principal-principal conflicts substantially different from the typical model of agency conflicts.

The interviewees' statements highlight the government's concern with the sustainability of state enterprises, but also indicate that these firms end up being more of a tool for political ends 
than a method for delivering value to society for the indirect investments made. As such, state companies are a means for government shareholders to exert power and prioritize results that favor their policies and not necessarily prioritizing results that are favorable to society or the sustainability of the firm itself. For details, see Chart 8.

Chart 8

Category: Government as Shareholder

Category Data

INT 1: It is obvious that private shareholders want return on capital, but they also want sustainability [...] I think that the government doesn't think about profitability, it thinks about politics, thinks about nominating people to important positions, and that these people don't contribute to the firm.

INT 2: Not just profit, not only profit, because just aiming for profit and forgetting about the social side, that this is a public firm, that it also has this mission, you know. [...] the ideal is a bit utopian, but it would be very close to what our boss wants. Which is the public, you

Government as know. The consumer is our boss.

Shareholder INT 3: State companies no longer invest for quality [...] Investment is very much related to subjectivity and, primarily, to the political relationship that the controlling interest has in the regions where investments will be made.

INT 4: The politician's argument that the firm has to fulfill its social function: the public interest, is a way for him to cloak the political interests. Not the interests of the population. INT 5: Often, when the majority shareholder is a state company, this brings with it a penalty for Brazilian companies, because they become subordinated to the Brazilian state enterprises, to a regime of controls that are much more extensive than for private firms.

Source: prepared by the authors (2019).

These points are also compatible with the view that when the government is a shareholder it intervenes more intensely in both firms' operations and in their regulation, making it difficult for companies to predict the actions of the regulatory agencies, creating a scenario of instability and of increased political and regulatory risk (Khanna \& Palepu, 1997).

The interviewees see the regulatory agency as influential with respect to the companies, but, in the final analysis, the agency is itself influenced by the government. For example, in some situations a regulatory agency may be a means of catalyzing the government's influence over the companies, as it exercises direct influence as shareholder, and indirect influence as regulator, even when it is not part of their governance structure. This is highlighted in Chart 9 and appendix A.

The interviewees' statements clearly illustrate the government's influence on the electric power industry as a whole and also on management decisions and the manner of directing business when the government has a controlling holding in public-private ownership companies. These findings are in line with arguments put forward by Lazzarini (2011), which, in turn, have been supported by Brey et al. (2012), for whom the government in Brazil utilizes its own distinctive methods of influencing firms. These methods are directly, through participation in their ownership structures, and, indirectly, through regulation.

When the government employs regulation as a method of interfering in companies, it triggers one of the greatest risks BEPI firms are exposed to and to which there are few means of defense. These firms can only conform to the guidelines of the regulatory agency and adopt compatible management standards. The interviewees felt a pressing need to emphasize that this causes instability in the BEPI and drives away investments that would be important for development of the research and infrastructure which would be needed for the industry to evolve over time. It is evident that the regulatory agency could improve its functioning in the industry, creating more mechanisms that contribute to development of the industry's firms. 
BBR

Chart 9

Categories: Regulatory agencies, Influence of the government on the industry, and MP 579/12

Category Dat

INT 1: Terrible, I think they need to improve a great deal [...] so that the regulator has the aim of attracting capital, not scaring it away.

INT 2: [...] its objective is to regulate, to audit [...]. That is its objective, but I do think that it has influence in the electric power industry.

INT 3: It can have a direct influence on the industry. Aneel was doing very well, at least from the market's perspective, until MP 579/12. [...] now, I can say, from experience, that at the

Regulatory agencies moment of truth, at the moment of truth, the government "polices" the regulatory agencies and the independent inspectors.

INT 4: The regulatory organizations must improve greatly. [...] the regulatory risk is very high. In fact, the electric power industry must improve as well.

INT 5: the relationship with the regulatory organization is the main risk factor. [...] I think that Aneel has transformed itself into a deliriously heavy-handed bureaucracy, which has gone well beyond what is reasonable for an industry regulator. [...] so, yes, it can have a negative influence. With respect to the CVM, I have a better impression, as a, let's say, a "Sheriff" of the capital markets.

INT 1: Depending on their lobby, their strength, companies gain credit with the government, there's no doubt. [...] the Ministry is political.

INT 2: Influence peddling, it's going to exist. Even in the family [...] So I see it, I see it as a Influence means of influence, yes, now, whether it's right? I don't think it is.

of the government on the industry INT 3: For example, in a state company, the regulator is more lax. In a state company, the regulator applies less pressure. In a private one, it looks at things differently [...] When a situation comes up that involves the government, the final decision is going to be the one that it wants. [...] The influence of the controlling interest is evident when there is a debt of favors to be repaid.

INT 5: When the government wants something and orders Aneel to do it, that's how it works. Very strange things, when the majority shareholder has an interest, are decided very quickly, as we saw in the case of MP 579/12.

INT 1: Out of the blue, the president made an announcement on the television that they're going to reduce charges by $20 \%$ and they're taking the concessions back. [...] There has to be a regulatory standard. [...] It's a complete mess. The companies are going bust.

INT 2: MP 579/12, passed in 2012, was a huge error.

INT 3: When MP 579/12 arrived, we saw what government influence on a regulatory agency is [...] When that barbarity was committed, Aneel should have taken a stand, but it didn't take a stand.

INT 4: Private investors need predictability. [...] So, MP 579/12 affected the companies, MP 579/12 the Eletrobrás group. Because the board of directors wasn't independent if it did that. So the board of directors was aligned with the interests of the controlling shareholder, which is the Federal government. The Federal government ordered it to renew the concession. [...] Celesc and Cemig, for example, did not renew. Because they had independent boards [...] there was political pressure, but the board was independent.

INT 5: More than anything, MP 579/12 expanded the possibilities for conflict [...] we saw it as abuse by the Federal controlling interest, in the case of the Eletrobrás group [...], they caused huge losses for the nation and for the shareholders, for the government itself and for the minority investors.

Source: prepared by the authors (2019).

It is also evident that there is a risk for these firms to make investments within the regulatory uncertainty that is illustrated by MP 579/12. This fact reveals that the Brazilian government (the concession granting authority) exerts a powerful influence on the industry by adopting policies and making demands that impact on the firms' businesses, ignoring the resulting adverse 
financial effects. Proof of this is the imbalance created by MP 579 which, when finally corrected in 2015, triggered average price increases for the consumer of 50\% when the so-called "tariff realism" was restored.

MP 579/12 also provides evidence of the possibility of governmental interference in the various interfaces of the BEPI, given how it has concentrated the roles of concession granting authority, regulator, and shareholder, as illustrated graphically in Figure 2, depicting the theoretical framework. Overall, these results are in agreement with Khanna and Palepu (1997). They argue that, where institutions are weak, there are risks of broken contracts, limitations on transference of profits, government failure to honor guarantees, and regulatory limitations. These combine to create a scenario of marked instability.

The interviewees' statements clearly illustrate the government's influence on the electric power industry, both on the industry as a whole, and through management decisions and the manner of directing business when the government has a controlling holding in public-private ownership companies. These results provide evidence of the importance of research that concerns itself with investigating the effects of government influence and presence as a shareholder, which here have been shown to be impacting on firms' financial performance, on their standing in the market, and on their leverage (Thomsen, \& Pedersen, 2000; Wu, 2010).

The interviewees' opinion on MP 579/12 is that it was a decision based on essentially political criteria and definitively not on technical grounds, generating extremely negative consequences for management and for the performance of the firms involved. This underscores the discretionary power of the regulator through the government's involvement as concession granting authority. The occurrence of this event had an even greater negative impact on attracting investment into the industry, confirming the direct influence that the government has on the regulated market.

These results contradict the position of Arvate et al. (2013). The authors view regulation as an institutional arm created by governments with different characteristics to solve problems when there are market failures. With MP 579/12 just the opposite occurred. The measure generated a situation of potential conflicts arising from an environment of permanent uncertainty. Figure 3 illustrates the accentuation of principal-principal conflicts caused by the presence of the government as a shareholder in regulated environments.

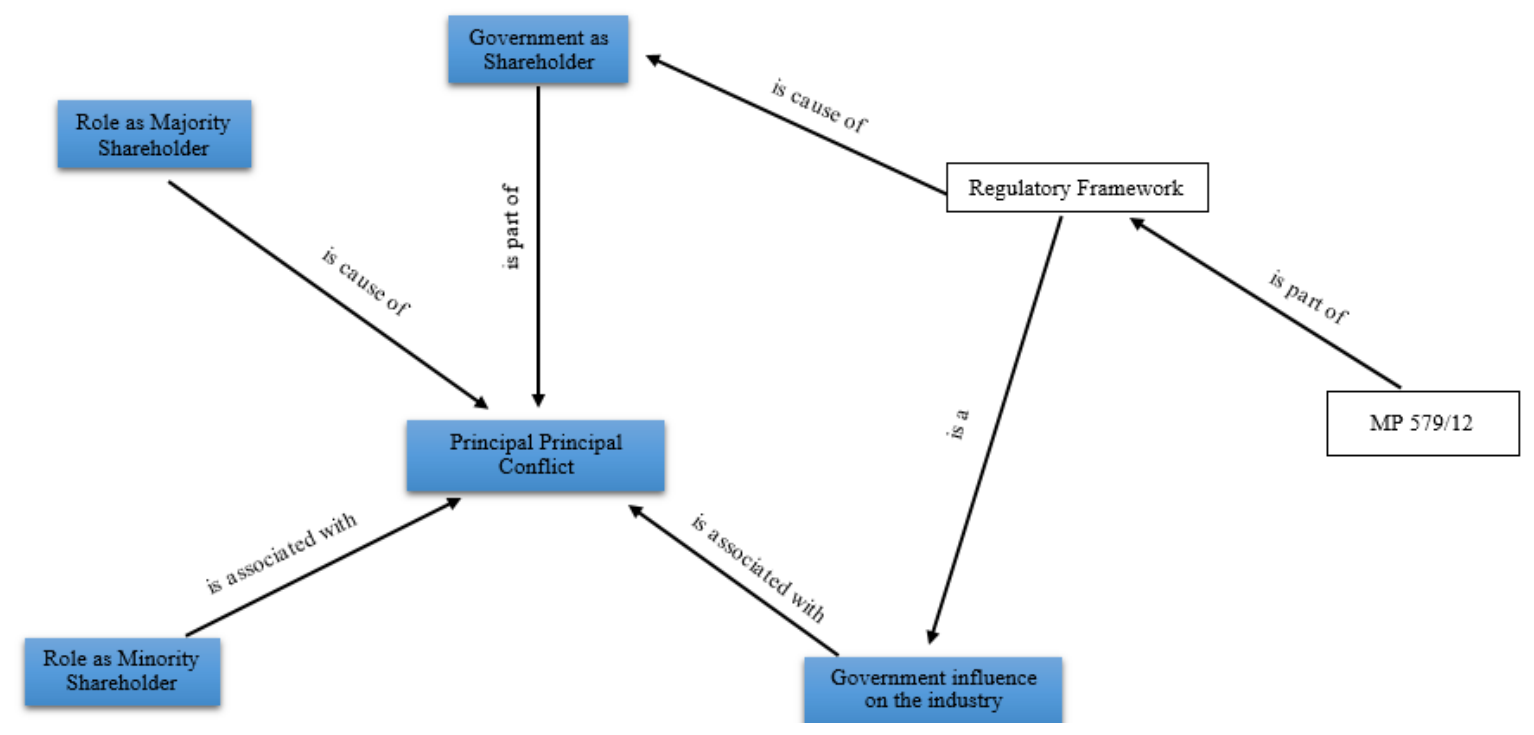

Figure 3. Principal-principal conflict Source: prepared by the authors (2019). 
State ownership can provide the firm with a useful channel to the government when it is seeking support for projects requiring investments that mature over the long term. Conversely, state ownership can also create a series of distortions caused by the government's inclination to pursue projects on the basis of political criteria. As such, in considering the many different factors that make principal-principal conflicts in public-private companies substantially different from the typical model of agency conflict, we are extending the boundaries of understanding of this phenomenon by incorporating elements from institutional theory into our analyses, which are particularly relevant to emerging economies because of the low level of institutional development in these settings.

In summary, we highlight how weak institutions, combined with an absence of effective governance mechanisms (the elements that should provide checks and balances on government interference) exacerbate conflicts between controlling and minority shareholders - in other words, creating principal-principal conflicts (Khanna \& Palepu, 1997; Morck et al., 2005). Better-developed institutions and stronger corporate governance could furnish useful options in the search for checks and balances to control opportunistic behavior and regulatory capture and, taken together, mitigate principal-principal conflict

\section{FINAL COMMENTS}

Working from the assumption that the government being a majority shareholder in publicprivate enterprises accentuates principal-principal conflicts caused by conflicts of interests, this study intends to fill gaps in the literature by considering this type of conflict specifically in relation to the Brazilian electric power industry. In doing this, we utilize the perspectives of institutional theory and agency theory. To achieve our goals, we employed a qualitative approach using data collection practices, in the form of interviews with directors and board members from the industry, that utilized a semi structured script.

Analysis and interpretation of this data enabled us to perceive that corporate governance in Brazil, and in the BEPI in particular, has evolved, but there is still a long way to go, since existing governance practices have little influence over management or on meeting international market standards.

It was found that the influence of minority shareholders is proportional to the size of their shareholdings, that they receive little information and, generally, are ignored in decision-making. Principal-principal conflicts would be ameliorated if both majority and minority shareholders had the same objectives. However, there is a conflict between political (not public) interests and private interests, in which the first is not always as interested in the financial health of the firm as the second. Additionally, the government's interest is catalyzed, since it influences firms both directly, as a shareholder, and indirectly, through regulation and pension funds.

Thus, it is considered that, although a process of privatization and denationalization has taken place in Brazil, the government still maintains positions in these companies. This is particularly evident in the electric power industry. We see this influence in management of the firms and in the unequal impact of decisions. Additionally, the government's direct influence on the regulated market creates a situation of conflicts in potential, and uncertainty for investors. The example of the MP 579/2012, based on a political agenda, was not favorable to the sustainability of many companies and not even, necessarily, favorable for society. In conclusion, we argue that the regulator could partner with other institutions, such as the IBGC and the CVM, to play its role in a manner that is more effective for the industry, creating mechanisms that contribute to development of these firms. 
Our results reinforce both of two conflicting views, one in favor of and one against government control, as summarized by Boubakri, Ghoul, Guedhami, and Megginson (2018). They are two sides of the same coin. On one side, the cost of government ownership is high because these firms are used as political tools to provide jobs, or improve regional development, without taking shareholder returns into account. On the flip side, such firms may be rescued at times of financial difficulty, and get privileged access to funding.

It remains to be determined whether the benefits of government ownership outweigh the costs. In the Brazilian scenario, in which investor protections are weak, government ownership is questionable and merits further debate. Future research could study this issue in greater depth, using quantitative methods, and the results may contradict or complement this view. One suggestion would be to quantify the magnitude of holdings in these firms, differentiating between majority and minority stakes. Studies of indirect government participation in firms are also needed. Abramov, Radygin, Entov, and Chernova (2017) consider that, in contrast with direct state ownership, indirect state control can have positive impact on firms' net equity and profit margins. This could be because of a more liberal regulatory regime when compared with direct management of state-owned enterprises.

Other future studies could be conducted to compare data from firms in the same industry but located in different countries. Along the same lines, we also suggest extending this research avenue to evaluate the traditional legal doctrines of different countries and their relationships with the institutions of corporate governance. Include other regulated industries and consider the qualifications of board members also represent worthwhile challenges and opportunities for researchers. As research into the subject advances, perceptions and explanations could be evaluated that have gone undetected in this study-because of the methods employed, the study design, and the theories utilized.

\section{REFERENCES}

Abramov, A., Radygin, A., Entov, R., \& Chernova, M. (2017). State ownership and efficiency characteristics. Russian Journal of Economics, 3(2), 129-157.

Arvate, P. R et al. (2013). Regulatory quality and performance of Latin American companies. In: Encontro Nacional da Associação Nacional dos Programas de Pósgraduação em Administração, Rio de Janeiro. Anais... EnANPAD.

Bardin, L. (2006). Análise de conteúdo (L. de A. Rego \& A. Pinheiro, Trads.). Lisboa: Ediçóes 70. (Obra original publicada em 1977)

Bauer, J. M. (2005) Regulation and state ownership: Conflicts and complementarities in EU telecommunications. Annals of Public and Cooperative Economics, v. 76, p. 51-177, 2005.

Bebchuk, L. A., \& Weisbach, M. S. (2010). The State of Corporate Governance Research, Review of Financial Studies, Society for Financial Studies, vol. 23(3), pp. 939-961, March.

Bertrand, M., Kramarz, F., Schoar, A., \& Thesmar, D. (2006). Politicians, firms and the political business cycle: Evidence from France. Unpublished working paper. University of Chicago.

Beuselinck, C., Cao, L., Deloof, M., \& Xia, X. (2017). The value of government ownership during the global financial crisis. Journal of corporate Finance, 42, 481-493.

Boubakri, N., El Ghoul, S., Guedhami, O., \& Megginson, W. L. (2018). The market value of government ownership. Journal of Corporate Finance, 50, 44-65. 
Branco, L., \& Balassiano, M. (2013). Principal versus principal conflicts in the Brazilian context. Investment Management and Financial Innovations, v. 10, n. 4, pp. 80-87.

Brasil, Lei 6385 de 07 de dezembro de 1976. (2015). Diário Oficial [da] República Federativa do Brasil, Poder Executivo. Disponível em: http:/www.planalto.gov.br/ccivil_03/leis/L6385. htm Acesso em 01 jun.

Brasil, Lei 6404 de 15 de dezembro de 1976. (2015). Diário Oficial [da] República Federativa do Brasil, Poder Executivo. Disponível em: http://www.planalto.gov.br/ccivil_03/leis/L6404consol. htm Acesso em 01 jun.

Brey, N. K.; Camilo, S. P. O.; Marcon, R.; \& Bandeira-de-Mello, R. (2014) Conexóes Políticas em Estruturas de Propriedade: O Governo Como Acionista em uma Análise Descritiva RAM, Rev. Adm. Mackenzie, 15(1), 98-124. SÃO PAULO, SP. JAN.-FEV.

Claessens, S., \& Fan, J. P. Corporate Governance in Asia: A Survey. International Review of Finance, 3(2). 2002.

Costa, L. (2018) Reuters. Disponível em : <https://br.reuters.com/article/businessNews/ idBRKBN1ET1QF-OBRBS>. Acesso em: 16 de dezembro.

Creswell, J. W. (2010). Estudo de pesquisa: método qualitativo, quantitativo e misto. Trad. Luciana de Oliveira da Rocha. 2. ed. Porto Alegre: Bookman.

Cuervo- Cazurra, A., \& Villalonga, B. (2000). Explaining the variance in the performance effects of privatization. Academy of Management Review, v. 25, p.581-590.

Cuervo-Cazurra, A., \& Dau, L. A. (2009). Promarket reforms and firm profitability in developing countries. The Academy of Management Journal, v. 52, p. 1348-1368.

Dalmácio, F. Z., \& Nossa, V. (2004). The agency theory applied to the investment funds. Brazilian Business Review, v. 1, n. 1, p. 31-59.

Dharwadkar, R., George, G., \& Brandes, P. (2000) Privatization in emerging economies: An agency theory perspective. Academy of Management Review, vol. 25, p. 650-669.

Eisenhardt, K. M. (1989). Agency theory: An assessment and review. The Academy of Management Review, v. 14, n. 1, p. 57-74, Jan.

Fan, J. H.; Wong, T. J.; Zhang, T. (2007) Politically connected CEOs, corporate governance, and Post-IPI performance of China's newly partially privatized firms. Journal of Financial Economics, v. 84, n. 5, p. 330-357.

Fontes Filho, J. R., \& Picolin, L. M. (2008). Governança corporativa em empresas estatais: avanços, propostas e limitaçóes. Revista de Administração Pública, v. 42, n. 6, 1163-1188.

Gomes, J. P. P., \& Vieira, M. M. F. (2009). O campo da energia elétrica no Brasil de 1880 a 2002. RAP Revista de Administraçâo Pública, Rio de Janeiro: p. 295-321, mar./abr.

Gul, F. A. (2006). Auditors' response to political connections and cronyism in Malaysia. Journal of Accounting Research, 44(5), 931-963.

Hoskisson, R. E., Eden, L., Lau, C. M., \& Wright, M. (2000). Strategy in emerging economies. Academy of management journal, 43(3), 249-267.

IBGC - Instituto Brasileiro de Governança Corporativa. (2015). Disponível em: www.ibgc.org. br/inter.php?id=18161. Acesso em 7 abr.

Jensen, M. C., \& Meckling, W. H. (1976). Theory of firm: managerial behaviour, agency costs and ownership structure. Journal of Financial Economics, p. 305-60. 
Johnson, S. G., Schnatterly, K., \& Hill, A. D. (2013). Board composition beyond independence: social capital, human capital, and demographics. Journal of Management, v. 39, p. 232-262.

Kaldor, N. 1980. Public or private enterprise-The Issue to be considered. In W. J. Baumol (Ed.), Public and private enterprises in a mixed economy: 1-12. New York: St. Martin's.

Khanna, T., \& Palepu, K. (1997). Why focused strategies may be wrong for emerging markets. Harvard Business Review, 75(4), 41-51.

La Porta, R., Shleifer, A., \& Lopez-de-Silanes, F. (1999). Corporate ownership around the world. The Journal of Finance, 54(2): 471-517.

Lazzarini, S. G. (2011). Capitalismo de Laços: os Donos do Brasil e suas Conexóes. Rio de Janeiro: Elsevier.

Lazzarini, S. G., \& Musacchio, A. (2010). Leviathan as a minority shareholder: A study of equity purchases by the Brazilian National Development Bank (BNDES), 1995-2003. SSRN Electronic Journal, p. 1995-2003.

Leal, R. P. C., \& Saito, R. (2003). Finanças corporativas no Brasil. ERA - eletrônica, 2(2), 1-15.

Li, J.; Qian, C. (2013) Principal-principal conflicts under weak institutions: a study of corporate takeovers in China. Strategic Management Journal, vol. 34, p. 498-508.

Loch, M., Marcon, R., da Silva, A. L. P., \& Xavier, W. G. (2018). Government's impact on the financial performance of electric service providers as both regulator and shareholder. Utilities Policy, 55, 142-150.

Mengistae, T., Xu, L. C. (2004). Agency theory and compensation of CEOs of Chinese state enterprises. Journal of Labor Economics, v. 22, p. 615-637.

Miles, M. B.; Huberman, A. M. (1994) Qualitative data analysis: an expanded sourcebook. [S.1.]: Thousand Oaks: Sage.

Morck, R., Wolfenzon, D., \& Yeung, B. (2005). Corporate governance, economic entrenchment, and growth. Journal of Economic Literature, v. 63, p. 655-720.

Mozzato, A. R., \& Grzybovski, D. (2011). Análise de conteúdo como técnica de análise de dados qualitativos no campo da administração: potencial e desafios. Revista de Administração Contemporânea, v. 15, n. 4, p. 731-747.

Musacchio, A., \& Lazzarini, S. G. (2015). Reinventando o capitalismo de Estado: o Leviata nos negócios: Brasil e outros países. São Paulo: Portfolio-Penguin.

North, D. C. (1990) Institutions, institutional change, and economic performance. Cambridge University Press, New York.

Nunes, E.; Ribeiro, L. M.; Peixoto, V. (2015) Agências reguladoras no Brasil. In: AVELAR, L.; CINTRA, A. O. (Orgs.) Sistema politico brasileiro: uma introdução. Cap 7, 3 ed: UNESP.

Okimura, R.; Silveira, A.; Rocha, K. (2007) Estrutura de propriedade e desempenho corporativo no Brasil. RAC-Eletrônica, v. 1, p. 119-135.

Peng, M. W., Wang, D. Y. L., \& Jiang, Y. (2008) An institution based view of international business strategy: a focus on emerging economies. Journal of International Business Studies, v. 39, p. 920-936.

Rocha, A. (2013). Valor Econômico. Disponível em: <https://www.valor.com.br/valor-investe/oestrategista/3147780/os-riscos-de-investir-em-acoes-de-estatais $>$. Acesso em: 16 de dezembro.

Saito, R., \& Silveira, A. (2008). Governança corporativa: custos de agência e estrutura de proprie $\neg$ dade. RAE - Revista de Administração de Empresas, 48(2), 79-86. 
BBR

17

44

Sarkar, J., \& Sarkar, S. (2008). Debt and corporate governance in emerging economies Evidence from India 1. Economics of Transition, 16(2), 293-334.

Shleifer, A., \& Vishny, R. (1997) A survey of corporate governance. Journal of Finance, v. 52(2), p. 737-783.

Silva, J. C. D., Xavier, W. G., Gambirage, C., \& Camilo, S. P. O. (2018). The Influence of Political Connections on the Cost of Capital and the Performance of Companies Listed on B3. BBR. Brazilian Business Review, 15(4), 317-330.

Silveira, A. D., Barros, L. A. B. C., \& Famá, R. (2008) Atributos Corporativos e Concentração Acionária no Brasil. Revista de Administração Eletrônica RAE.

Thomsen, S.; Pedersen, T. (2000) Ownership structure and economic performance in the largest European companies. Strategic Management Journal, v. 21, n. 6, p. 689-705..

Stan, C., \& Bruton, G. D. (2013). Theory of the (State-Owned) Firm. In Academy of Management Proceedings (Vol. 2013, No. 1, p. 14904). Briarcliff Manor, NY 10510: Academy of Management.

Wiziack, J. (2018). Folha Online. Disponível em : <https://www1.folha.uol.com.br/ mercado/2018/06/para-manter-influencia-apos-temer-mdb-prepara-loteamento-de-agencias. shtml>. Acesso em: 16 de dezembro.

Wu, H. (2010) Can minority state ownership influence firm value? Universal and contingency views of its governance effects. Journal of Business Research, 64(8), 839-845.

Young, M.; Peng, M.; Ahlstrom, D.; Bruton, G.; Jiang Y. (2008) Corporate governance in emerging economies: A review of the principal-principal perspective. Journal of Management Studies, v. 45, p. 196-220. 


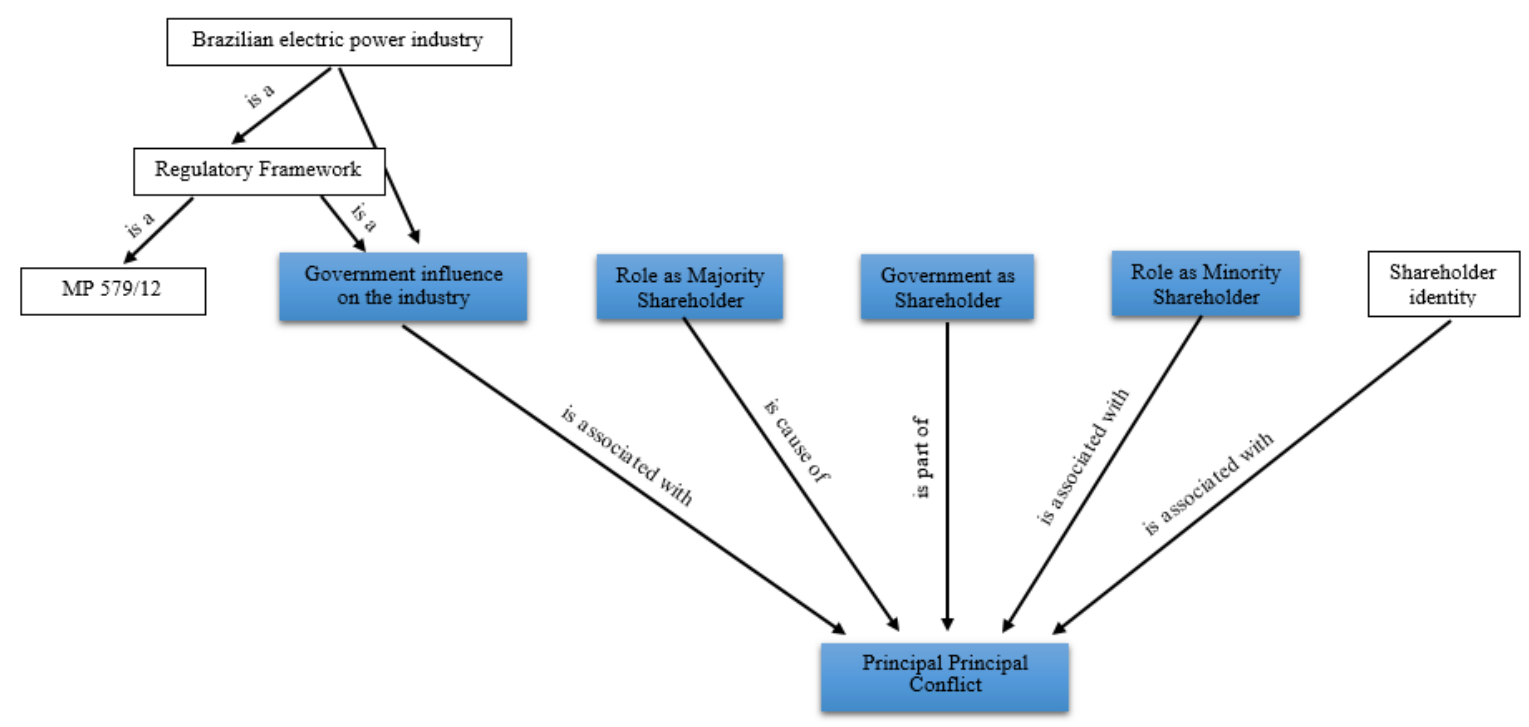

Source: prepared by the authors (2019).

\section{APPENDIX B - INTERVIEW SCRIPT}

\begin{tabular}{|c|c|c|}
\hline Subjects & Categories & Questions \\
\hline $\begin{array}{l}\text { Corporate } \\
\text { governance }\end{array}$ & $\begin{array}{l}\text { Corporate } \\
\text { governance in } \\
\text { Brazil }\end{array}$ & $\begin{array}{l}\text { What are your perceptions of corporate governance in Brazil? } \\
\text { Whose responsibility is it to improve governance: the securities commission, } \\
\text { the companies, the government? } \\
\text { Or should it be voluntary, via the stock exchange, the Brazilian Corporate } \\
\text { Governance Institute? } \\
\text { Is the electric power industry keeping pace with other industries or does it } \\
\text { need to improve? }\end{array}$ \\
\hline $\begin{array}{l}\text { Principal- } \\
\text { principal }\end{array}$ & $\begin{array}{l}\text { Principal- } \\
\text { principal conflict } \\
\text { Role of majority } \\
\text { shareholder }\end{array}$ & $\begin{array}{l}\text { Would you say that shareholder control is abused in this industry? } \\
\text { How do you view the relations between minority and majority shareholders } \\
\text { and how do you view minority shareholder protection in Brazil? } \\
\text { And, depending on the identity of the majority shareholder, in your opinion } \\
\text { can they affect performance? }\end{array}$ \\
\hline $\begin{array}{l}\text { Shareholder } \\
\text { identity }\end{array}$ & $\begin{array}{l}\text { Government as } \\
\text { shareholder }\end{array}$ & $\begin{array}{l}\text { Is it possible that there is a distinction between the performance of public- } \\
\text { private firms and private firms? } \\
\text { In your view, does this happen more in state-owned or private enterprises? }\end{array}$ \\
\hline $\begin{array}{l}\text { Corporate } \\
\text { governance }\end{array}$ & $\begin{array}{l}\text { Board of } \\
\text { directors }\end{array}$ & $\begin{array}{l}\text { In your view, is there a relationship between the composition of boards of } \\
\text { directors and performance in firms in this industry? }\end{array}$ \\
\hline $\begin{array}{l}\text { Regulatory } \\
\text { framework }\end{array}$ & $\begin{array}{l}\text { Regulatory } \\
\text { agencies } \\
\text { Influence of the } \\
\text { government on } \\
\text { the industry }\end{array}$ & $\begin{array}{l}\text { What are your perceptions of whether the role (or activities) of the regulator } \\
\text { is(are) working in Brazil? } \\
\text { Can it affect the performance of firms in this industry? } \\
\text { Could you give some examples? } \\
\text { Do you perceive any type of favoritism by industry regulators in terms of } \\
\text { shareholder identity? }\end{array}$ \\
\hline & MP 579/12 & Emerged during analysis \\
\hline
\end{tabular}

Source: prepared by the authors (2019). 